\title{
Erratum to: The Contribution of the Cerebellum in the Hierarchial Development of the Self
}

\author{
Mehmet Emin Ceylan ${ }^{1}$ • Aslıhan Dönmez ${ }^{2}$ • Barıș Önen Ünsalver ${ }^{3}$
}

Published online: 16 May 2015

(C) Springer Science+Business Media New York 2015

Erratum to: Cerebellum

DOI 10.1007/s12311-015-0675-7

The original paper of this article unfortunately contains error. The name of the author "Barış Önen Ülsalver" was published incorrectly. This should have been written as "Barış Önen Ünsalver". With this, the authors would like to publish this correction note.

The online version of the original article can be found at http://dx.doi.org/ 10.1007/s12311-015-0675-7.

\footnotetext{
Aslihan Dönmez

draslihandonmez@gmail.com

1 Department of Psychology, Üsküdar University, Istanbul, Turkey

2 Department of Psychiatry, Gazi University Hospital Beșevler, Ankara, Turkey
}

3 Üsküdar University, Istanbul, Turkey 